\title{
Capital formation in fisheries sector in India: trends, compositional changes and potential implications for sustainable development
}

\author{
A Suresh ${ }^{\text {a* }}$ and Shinoj Parappurathu ${ }^{\text {b }}$ \\ aCAR-Central Institute of Fisheries Technology, Kochi-682029, Kerala, India \\ ${ }^{b}$ ICAR-Central Marine Fisheries Research Institute, Kochi-682018, Kerala, India
}

\begin{abstract}
This paper analyses the trends in capital formation in fisheries sub-sector and the responsiveness of fisheries sector to capital formation during the period of 1990-91 to 2014-15. We find structural breaks in capital formation, coinciding with policy changes. There has been a deceleration in capital formation immediate post-liberalisation. The share of fisheries sub-sector in agricultural gross domestic product (GDP) has gradually increased, from $4.3 \%$ in $1994-95$ to $5.4 \%$ in 2014-15. Correspondingly, the share of fisheries sub-sector in gross fixed capital formation (GFCF) in agricultural sector has increased from $3.4 \%$ to $9.7 \%$. However, the efficiency of investment in the fisheries sub-sector has declined; the incremental capital output ratio (ICOR) has increased from 3.2 to 8.3 during this period. The fast decline of the efficiency of capital can be attributed to over-capitalisation of some segments of this sub-sector, particularly marine fisheries characterised by a large number of mechanised fishing vessels. The public capital formation in fisheries as a share of the total pubic capital formation is very low. Inland fisheries also face sustainability issues in terms of environmental degradation. Improving the capital productivity warrants implementation of norms of sustainable fisheries. This requires prioritization of segments for capital infusion and prioritization of geographical locations.
\end{abstract}

Keywords Capital formation, Investment, Fisheries, Efficiency, Sustainability

JEL classification O21, Q180, Q220, Q010

\section{Introduction}

Sustainable development goals (SDGs) of the United Nations (UN) are more ambitious than their immediate precursor, the Millennium Development Goals (MDGs). These warrant humanity to respond to the global issues including climate change and poverty in a targeted manner. The SDGs cover a range of interconnected issues spanning from economic growth to social justice and environmental quality. The UN has identified 17 sustainable development targets to be achieved by 2030. These relate to poverty, hunger, food and nutritional security, gender equality, availability and sustainable management of water, sustainable economic growth, full and productive employment and

\footnotetext{
*Corresponding author: sureshcswri@gmail.com
}

decent work for all, conservation and sustainable use the oceans, seas and marine resources, to mention a few (UNDP 2018).

The 2030 Agenda of sustainable development aims to increase the contribution and conduct of fisheries and aquaculture towards food security, nutrition and natural resources so as to ensure sustainable development in economic, social and environmental terms (FAO 2016). Food and Agricultural Organization provide detailed statistics on the trends in production of fish and other aquatic animals. As on 2014, the global capture fisheries production was 93.4 million tonnes -81.5 million tonnes from marine waters and 11.9 million tonnes from inland waters. Another 73.8 million tonnes of fish and other aquatic animals were produced 
through aquaculture. This production comprised mainly of finfish (more than 60\%), mollusc (about 20\%) and crustaceans (about 8\%) and other aquatic organisms. Aquaculture is increasingly contributing to the global fish consumption. The share of aquaculture to human fish consumption was $7 \%$ in 1974 that gradually increased to $45 \%$ in 2014 (FAO 2016). Further, an estimated 56.6 million people were engaged in upstream of the capture fisheries and aquaculture in 2014. This statistics clearly point towards the role the fisheries sub-sector can play in achieving the sustainable development goals globally.

In India, the importance of fish in achieving the sustainable development goals can be gauged from its current contributions towards food and nutritional security, provision of livelihood, employment generation and gender equity and to the overall growth target of agricultural sector, currently pegged at $4 \%$ per year. India produced 10.7 million tonnes of fish in 2015-16 from a mere 0.75 million tonnes in 1951 lifting the annual per capita availability of fish in India from 1.9 to $5.04 \mathrm{~kg}$. Translated into protein, it increased from $0.5 \mathrm{~g}$ to $1.53 \mathrm{~g}$. This happened mainly due to the increased supply of fresh water fish (Barik 2017). Several factors including research, extension, and investments in infrastructure and institutions have contributed to this. About 14 million people are dependent on fisheries for livelihood, who are generally economically and socially marginalised (GoI 2014). Development of fisheries sub-sector is one pathway through which they can be mainstreamed.

By 2030, domestic demand for fish is projected to 16 million tonnes (ICAR 2012), warranting a production growth of $2.2 \%$ a year for balancing the demand and supply. Export demand is also bound to rise. In 201718 , export of fisheries was US $\$ 6.8$ billion or $2.2 \%$ of the total merchandise exports. Since 2010-11, fisheries exports have been increasing at annual rate of $16.7 \%$.

Several studies have examined capital formation in Indian agriculture, focussing on composition of capital formation and trends and implication thereof (Rao 1989, 1997; Shetty 1990; Mitra 1996; Dhawan 1996; Gulati \& Bathla 2001), and the relative shares of public and private sectors in capital formation and the interrelationships between these (Shetty 1990; Mishra \& Chand 1995; Bathla 2014). The key conclusions from these studies are (i) private investment in agriculture is propelled by public spending on agriculture and infrastructure, institutional credit and demand for raw material for agro-processing, especially in initial periods; and (ii) massive investment in rural development and agriculture is required for reducing poverty and inter-regional disparities (e.g., Fan \& Hazell 2000; Singh 2011).

While the agricultural investment in general has been much researched, a disaggregated analysis by subsectors is rare. Of particular mention is the fisheries sub-sector. As it is considered as a sunrise sector with heavy export orientation, and being a water-based enterprise, the issue of capital formation in fisheries is quite different. This sub-sector has also witnessed significant technological developments in recent times. Cage farming, deep sea fishing and value addition have received much focus in the marine fisheries. Government of India has initiated several activities under the blue revolution scheme. The Sagarmala scheme of the Government of India also envisages inclusion of fisheries as its integral component.

With this background, this paper examines trends in the capital formation in fisheries sub-sector, and its potential implications on sustainable development with the following specific objectives:

1. To examine the trend in capital formation in fisheries sub-sector India, and juxtapose with the trends in the general economy and agriculture \& allied sectors;

2. To identify the responsiveness of fisheries subsector to capital formation and estimate incremental capital output ratio.

Rest of the paper is organized as follows. Data sources and methodology are provided in section 2. Key findings are presented and discussed in section 3. Concluding remarks are made in the last section.

\section{Data and method}

The analysis in this paper is based on data on Gross Domestic Product (GDP) and capital formation for the period 1990-91 to 2014-15 collected from the National Accounts Statistics of the Government of India.

\subsection{Identifying structural break in time series}

By plotting of the time series, we find existence of structural breaks in capital formation. Therefore, we 
identify structural break following Bai \& Perron (2003). We consider the following multiple linear regression model with $m$ breaks ( $m+1$ regimes) with $h$ as minimum length assigned to the segment:

$y_{t}=x_{t}^{\prime} \beta+z_{t}^{\prime} \delta_{j}+u_{t} t=T_{j-1}+1, \ldots \ldots \ldots, T_{j}, j=1, \ldots$, $m+1$.

where, $y_{t}$ is the observed dependent variable at time $t$; $x_{t}(p \times 1)$ and $z_{t}(q \times 1)$ are vectors of covariates and $\beta$ and $\delta_{j}(j=1, \ldots, m+1)$ are the corresponding vectors of coefficients; $u_{t}$ is the disturbance at time $t$. The indices $\left(T_{1}, \ldots, T_{m}\right)$ or the break points, are explicitly treated as unknown (we use the convention that $T_{0}=0$ and $T_{m}+1$ $=T$ ). The purpose is to estimate the unknown regression coefficients together with the break points when $\mathrm{T}$ observations on $\left(y_{t}, x_{t}, z_{t}\right)$ are available. This is a partial structural change model since the parameter vector $\beta$ is not subject to shifts and is estimated using the entire sample. When $p=0$, we obtain a pure structural change model where all the coefficients are subject to change. The variance of $u_{t}$ need not be constant. Indeed, breaks in variance are permitted provided they occur at the same dates as the breaks in the parameters of the regression.

The multiple linear regression equation (1) may be expressed as a matrix:

$Y=X \beta+\bar{Z} \delta+U$

Where, $Y=\left(y_{1}, \ldots, y_{T}\right)^{\prime}, X=\left(x_{1}, \ldots, x_{T}\right)^{\prime}, U=\left(u_{1}, \ldots, u_{r}\right)^{\prime}, \delta$ $=\left(\delta_{1}^{\prime}, \delta_{2}{ }^{\prime}, \ldots, \delta^{\prime}{ }_{m+1}\right)$, and $\bar{Z}$ is the matrix which diagonally partitions $\mathrm{Z}$ at $\left(T_{1}, \ldots, T_{m}\right)$, i.e. $\bar{Z}=\operatorname{diag}\left(Z_{1}, \ldots, Z_{m+1}\right)$ with $Z_{i}=\left(z r_{i-1}+1, \ldots z r_{i}\right)^{\prime}$. We denote the true value of a parameter with a 0 superscript. In particular, $\delta^{0}=\left(\delta_{1}^{0^{\prime}}\right.$, $\left.\ldots, \delta^{0 \prime}{ }_{m+1}\right)^{\prime}$ and $\left(T_{1}^{0}, \ldots, T_{m}^{0}\right)$ are used to denote, respectively, the true values of the parameters $\delta$ and the true break points. The matrix $\bar{Z}^{0}$ is the one which diagonally partitions $\mathrm{Z}$ at $\left(T_{1}^{0}, \ldots, T_{m}^{0}\right)$ Hence, the datagenerating process is assumed to be

$$
Y=X \beta^{0}+\bar{Z}^{0}+U
$$

For each m-partition $\left(T_{1}, \ldots, T_{m}\right)$, the associated leastsquares estimates of $\beta$ and $\delta_{j}$ are obtained by minimizing the sum of squared residuals

$$
(Y-X \beta-\bar{Z} \delta)^{\prime}(Y-X \beta-\bar{Z} \delta)=\sum_{i=1}^{m+1} \sum_{t=T_{t-1}+1}^{T_{i}}\left[y_{t}-x_{t}^{\prime} \beta-z_{t}^{\prime} \delta_{i}\right]^{2}
$$

Let $\hat{\beta}\left(\left\{T_{j}\right\}\right)$ and $\hat{\delta}\left(\left\{T_{j}\right\}\right)$ denote the estimates based on the given m-partition $\left(T_{1}, \ldots, T_{m}\right)$ denoted $\left\{T_{j}\right\}$
Substituting these in the objective function and denoting the resulting sum of squared residuals as $S_{T}\left(T_{1}, \ldots, T_{m}\right)$ the estimated break points $\left(\hat{T}_{1}, \ldots, \hat{T}_{m}\right)$ are such that $\left(\hat{T}_{1}, \ldots, \hat{T}_{m}\right)=\operatorname{argmin}_{T_{1}, \ldots \ldots \ldots T_{m}} S_{T}\left(T_{1}, \ldots, T_{m}\right)$ where the minimization is taken over all partitions $\left(T_{1}, \ldots, T_{m}\right)$ such that $T_{i}-T_{i-1} \geq q$. Thus the break-point estimators are global minimizers of the objective function. The regression parameter estimates are the estimates associates with the m-partition $\left\{T_{j}\right\}$, i.e. $\hat{\beta}=\hat{\beta}\left(\left\{T_{j}\right\}\right)$, $\hat{\delta}\left(\left\{T_{j}\right\}\right)$. Since, the break points are discrete parameters and can only take a finite number of values, they can be estimated by a grid search. This method becomes rapidly computationally excessive when $m>2$. Instead a dynamic programming algorithm that allows computation of estimates of the break points as global minimizers of the sum of squared residuals was devised here to efficiently estimate the optimal break points for the series starting from one to the maximum allowed by $\mathrm{T}$ and $\mathrm{h}$. In the present case, we had a sample size of 25 observations (1990-91 to 2014-15) and with the selected value of $h=4$ ( 15 per cent trimming of total observations), the maximum allowed breaks were 5 . Among the various combinations of break points, the best one was selected based on BIC criterion.

\subsection{Incremental capital output ratio (ICOR)}

Incremental capital output ratio (ICOR) is a key parameter that determine the investment requirement and, therefore, economic growth. It assesses the marginal investment required for a sector to produce an additional unit of output. In that sense, ICOR captures the technical relationship between investment and additional productive capacity. The major determinants of the ICOR are the technical conditions and structural configurations of the economy. The concept of ICOR in development planning is introduced by the popular Harrod- Domar (HD) model, where ICOR is defined as the ratio of the investment rate to growth rate for a particular period. The ICOR is calculated using some standard assumptions used in the HD model, viz., economy is on steady growth path; there is no lag between investment and generation of additional productive capacity, full capacity utilisation, and an unchanging production structure within an economy. There were considerable discussions on the applicability of the HD model to the Indian economy, which are more of rural in nature. However, the model is being used to calculate the investment requirement, 
notwithstanding its inability to respond to the rigidities and flexibilities of the Indian economy (Planning Commission 2012).

In the Harrod-Domar framework, the ICOR is calculated by dividing the investment ratio by the growth rate of GDP, i.e.

ICOR $=i / g$

Where, $\mathrm{i}=$ Investment/ GDP, and $\mathrm{g}=$ growth rate of GDP.

The ICOR is calculated cumulatively for certain period of time, based on the structural breaks identified. The cumulative calculation of ICOR used the following specification:

$$
I C O R=\sum_{i=1}^{n} \frac{G F C F_{t}}{\left(Y_{n}-Y_{0}\right)}
$$

Where, $\mathrm{GFCF}_{\mathrm{t}}=$ Gross Fixed Capital Formation for the year $\mathrm{t} ; \mathrm{Y}_{\mathrm{n}}=\mathrm{GDP} /$ Value added in the terminal year of the period, and $\mathrm{Y}_{0}=\mathrm{GDP} /$ Value added in the base year of the period.

\subsection{Investment elasticity of growth (IEG)}

The investment elasticity of growth shows responsiveness of GDP to changes in investment (Qureshi et al. 2015). In this paper, the elasticity has been estimated for agricultural sector as a whole, and separately for fisheries sub-sector:

$$
\text { Elasticity }=\frac{\delta G D P}{G D P} * \frac{G F C F}{\delta G F C F}
$$

Where, $\delta$ indicates change in the respective variables. However, since the interval between two structural break consists of a time series, the elasticity is calculated as the ratio of the trend growth rates of GDP and GFCF (estimated by using semi-log growth model). Though this method excludes the influence of many variables that determine GDP growth, it provides an approximation of the elasticity values, and has been used in previous studies (Bhalla 1987).

\section{Results and discussion}

GFCF in India is dominated by two major types of investments; construction and "machinery and equipment" (Planning Commission 2012). However, over the years, the share of machineries and equipment has been increasing in the overall GFCF. Also noteworthy is that the share of both construction and machinery as a percentage of the GDP is on the increase, indicating that the investment in the economy is rising. However, based on the type of institutions involved in the investment process, it can be noted that after reforms period of 1991, the share of public sector in the construction activities has increased, with a corresponding decline the share of the machinery, a reversal of the trend in the pre-reform period. This could be due to gradual withdrawal of the economy from the production role, and an increased focus on infrastructure development. One of the major line of thought of the economic reforms is gradual withdrawal of the state from direct production, and concentrating on creation of an environment including infrastructure development, and institutional reforms enabling investment and production. The private sector has historically concentrated more in investment towards machinery and equipment, and the share of investment on this heads has always remained higher than that in construction. This trend is largely applicable for all sections of the economy including agriculture and allied sectors.

\subsection{Structural changes in India's GDP growth}

Over years, Indian economy has witnessed a structural change characterised by a continuously sliding share of agriculture in GDP and an increasing share of services sector. The share of the agricultural sector in the GDP has reduced from $35.7 \%$ in $1980-81$ to $29.5 \%$ in $1991,22.3 \%$ in $2000-01,14.5 \%$ in $2010-11$ and further to $13.9 \%$ in $2017-18$. Such a sharp decline in the share of agricultural sector is also associated with an increase in the share of service sector, from $37.6 \%$ in $1980-81$ to $53.9 \%$ in $2017-18$. The share of secondary sector has almost remained constant, ranging between $25.7 \%$ to $29.1 \%$ during the period. Thus, the growth has bypassed industrial sector and is driven more by services sector. Between 1999-00 and 201516 , the share of crop sector in total value of output from agricultural sector has declined from $69.0 \%$ to $58.1 \%$, whereas that of livestock and fisheries has increased (figure 1). This trend is generally pointing to the diversification of agricultural sector towards high value commodities, like fruits, vegetables, and for high value protein-rich food such as milk, meat and fish. Such a trend has been triggered by a multitude of 


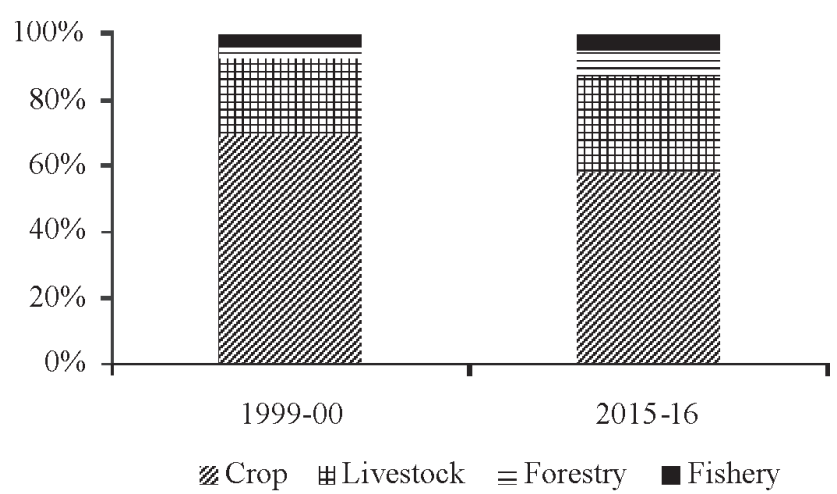

Figure 1. Change in share of crop, livestock, forestry and fishery sectors in value of output (current prices), 1999-2000 and 2015-16

Source: Authors' calculations based on GoI [a].

factors- high per capita income growth, change in taste and preferences of the consumers and population growth, to mention a few (Delgado et al. 1999; Joshi et al. 2004; Birthal \& Taneja 2006).

\subsection{Public and private capital formation in agriculture}

The composition of capital formation by institution, i.e. public and private, has undergone significant changes (figure 2). At aggregate level, the share of public capital formation has been continuously declining, from $44.6 \%$ in $1992-93$ to $22.5 \%$ in 2014 15. There could be several factors contributing to this. First, this is in tandem with policy initiatives to promote private capital formation. Second, the government has also gradually reduced its focus on certain areas, which targeted delivery of social goods. As on 2014-15, the share of private sector capital formation stands at around $77.5 \%$.

\subsection{Structural breaks in capital formation}

In this section, we identify structural breaks or secular acceleration/deceleration that could have been present in the capital formation series due to abrupt changes in policies. The methodology proposed by Bai \& Perron (2003) is used considering its ability to identify multiple structural breaks in data series using an efficient dynamic programming algorithm. Balakrishnan \& Parameshwaran (2007) and Chand \& Parappurathu (2012) have followed this approach to identify break dates in the GDP. Structural breaks have been identified separately for overall capital formation; capital formation in agricultural and allied sectors and that in fisheries sector.

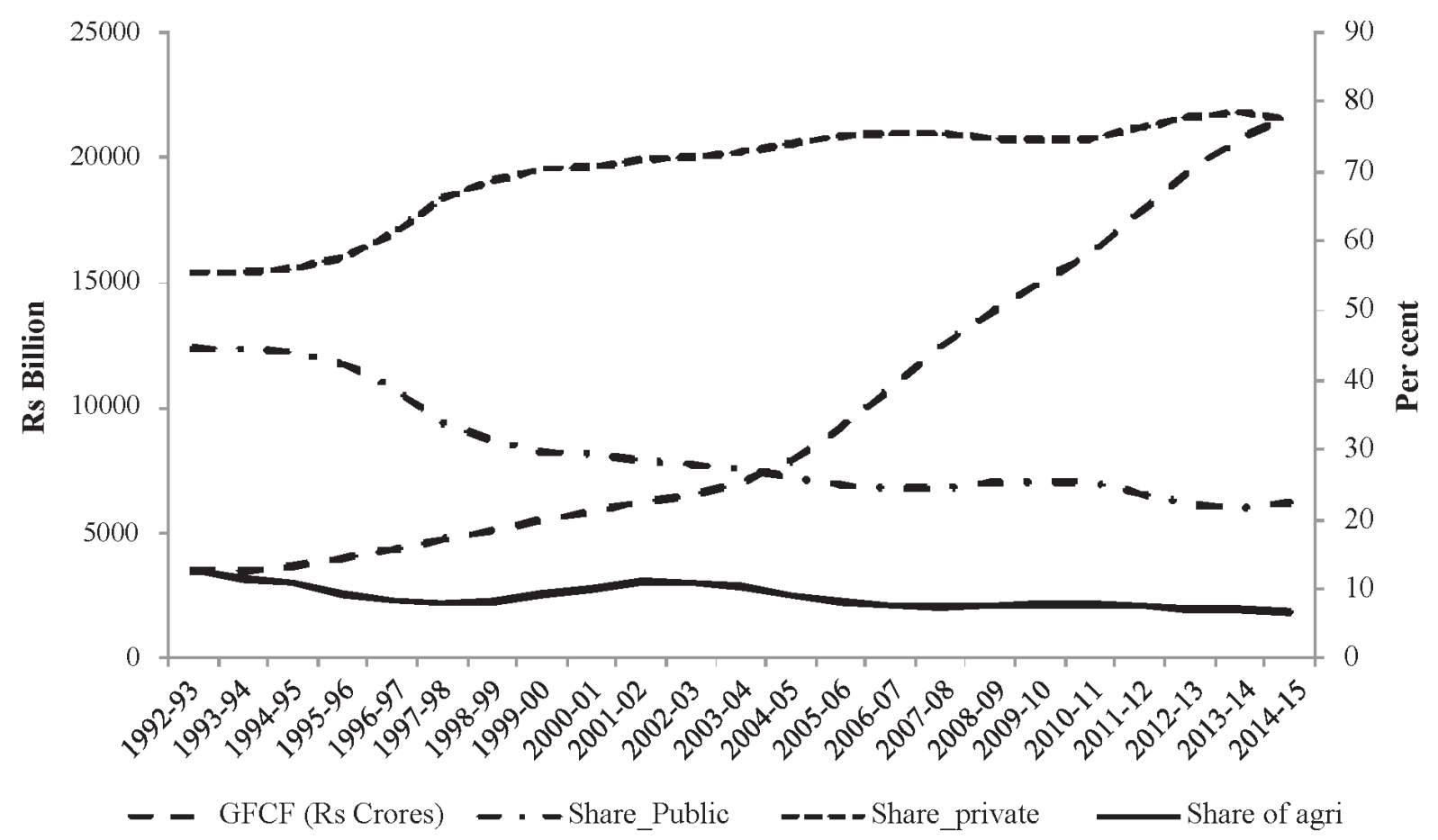

Figure 2. Trend in gross fixed capital formation (GFCF) and share of public and private sectors, 1991-92 to 2014-15 (2004-05 constant prices)

Source: Authors' calculations based on GoI[b]. 
Table 1. Results of the multiple break points

\begin{tabular}{|c|c|c|c|c|c|c|c|c|}
\hline Series & $\begin{array}{l}\text { Number of } \\
\text { breaks } \\
\text { estimated } \\
\quad(h=4)\end{array}$ & & & Break points & & & RSS & BIC \\
\hline \multirow{5}{*}{$\begin{array}{l}\text { Total capital } \\
\text { formation }\end{array}$} & $\mathrm{m}=1$ & 2003-04 & & & & & 1.89 & 19.37 \\
\hline & $m=2$ & $1997-98$ & $2005-06$ & & & & 0.91 & 7.48 \\
\hline & $\mathrm{m}=3$ & 1996-97 & 2003-04 & 2008-09 & & & 0.45 & -3.47 \\
\hline & $\mathrm{m}=4$ & $\begin{array}{c}1994-95^{+} \\
{[1993-94 /} \\
1996-97]\end{array}$ & $\begin{array}{c}2000-01^{+} \\
{[1998-99 /} \\
2001-02]\end{array}$ & $\begin{array}{c}2004-05^{+} \\
{[2003-04 /} \\
2005-06]\end{array}$ & $\begin{array}{c}2009-10^{-} \\
{[2008-09 /} \\
2011-12]\end{array}$ & & 0.28 & -8.65 \\
\hline & $\mathrm{m}=5$ & 1994-95 & 1998-99 & $2002-03$ & 2006-07 & $2010-11$ & 0.22 & -7.71 \\
\hline \multirow{5}{*}{$\begin{array}{l}\text { Capital } \\
\text { formation in } \\
\text { agriculture }\end{array}$} & $\mathrm{m}=1$ & $2000-01$ & & & & & 1.62 & 15.42 \\
\hline & $\mathrm{m}=2$ & 1998-99 & 2006-07 & & & & 0.37 & -14.77 \\
\hline & $\mathrm{m}=3$ & $\begin{array}{l}2000-01^{-} \\
{[1999-01 /} \\
2001-02]\end{array}$ & $\begin{array}{l}2003-04^{+} \\
{[1999-01 /} \\
2005-06]\end{array}$ & $\begin{array}{c}2007-08- \\
{[2006-07 /} \\
2009-10]\end{array}$ & & & 0.27 & -16.13 \\
\hline & $\mathrm{m}=4$ & 1993-94 & $2000-01$ & 2003-04 & 2007-08 & & 0.26 & -11.00 \\
\hline & $\mathrm{m}=5$ & 1993-94 & 2000-01 & $2002-03$ & 2006-07 & 2010-11 & 0.24 & -5.19 \\
\hline \multirow{5}{*}{$\begin{array}{l}\text { Capital } \\
\text { formation } \\
\text { in fisheries }\end{array}$} & $\mathrm{m}=1$ & 1998-99 & & & & & 3.07 & 31.44 \\
\hline & $\mathrm{m}=2$ & 1998-99 & 2007-08 & & & & 1.39 & 18.08 \\
\hline & $\mathrm{m}=3$ & 1994-95 & 1998-99 & $2007-08$ & & & 0.85 & 12.41 \\
\hline & $\mathrm{m}=4$ & $\begin{array}{c}1994-95^{+} \\
{[1992-93 /} \\
1995-96]\end{array}$ & $\begin{array}{c}1998-99- \\
{[1997-98 /} \\
1999-00]\end{array}$ & $\begin{array}{c}2005-06- \\
{[2004-05 /} \\
2007-08]\end{array}$ & $\begin{array}{c}2010-11^{+} \\
{[2009-10 /} \\
2012-13]\end{array}$ & & 0.58 & 9.35 \\
\hline & $\mathrm{m}=5$ & 1994-95 & 1998-99 & $2002-03$ & 2006-07 & 2010-11 & 0.53 & 13.63 \\
\hline
\end{tabular}

Note: Figures in the parentheses indicate 95 per cent confidence intervals using the procedure given by Bai (1997); The signs (+/-) in the superscripts indicate acceleration and deceleration respectively.

Source: Authors' calculations based on GoI[b].

Results of the estimation are presented in table 1. For the selected minimum break length (h) of 4 , the dynamic estimation procedure returned five possible results ranging from one break point to five break points. The optimum number of breaks was determined based on Bayesian Information Criteria (BIC). Accordingly, an optimum number of 4 breaks (199495, 2000-01, 2004-05 and 2009-10) were selected for the series of overall capital formation which are considered for further analysis in this paper.

\subsection{Trends in capital formation in agriculture and fisheries}

The trend in the gross fixed capital formation in Indian agriculture shows a varied picture (figure 3). During the post-liberalisation period, the GFCF has registered a trend growth of $8.2 \%$ per year till 2000-01, which slightly lowered during 2000-01 to 2004-05, as noted in table 2. The year 2004-05 coincided with a change in government policy. The trend growth of GFCF rose to 14.0 per cent during 2004-05 to 2009-10, but has considerably lowered to 7.7 per cent during 2009-10 to 2014-15. This trend is highly correlated with the trend in the overall GDP as well. The immediate postreform period has been widely recognised to have impacted Indian economy, particularly agricultural sector adversely. The GFCF in agriculture has been lower than that of GFCF in the overall economy during all the sub-periods. The highest growth in GFCF in agriculture is noted during the period of 2004-05 to 2009-10, and the lowest during 2009-10 to 2014-15. The trend in the GFCF in agriculture sector has declined to the lowest point in the 2009-10/ 2014-15 period. However, its impacts on GDP agriculture are not so 


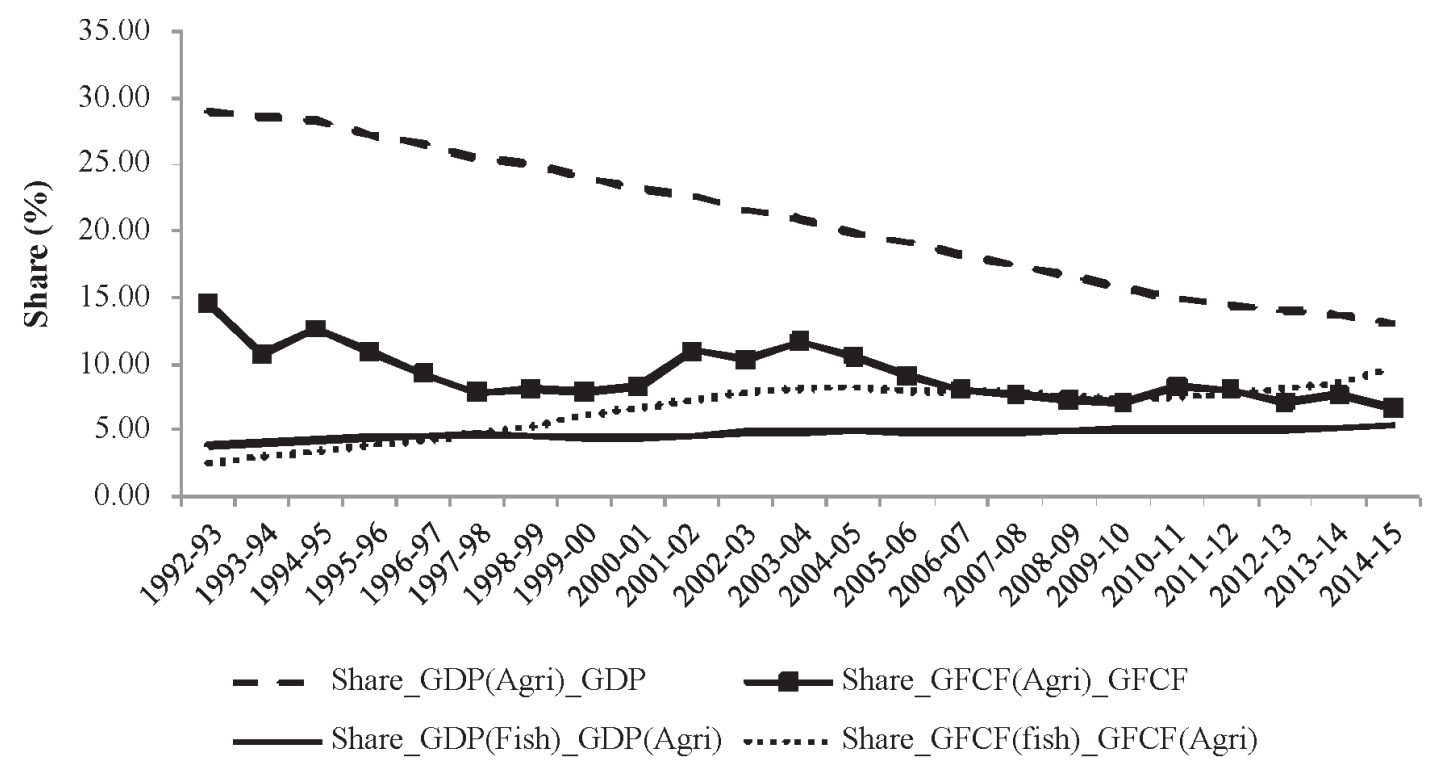

Figure 3. Trends in the share of GDP (agriculture) in total GDP, GFCF (agriculture) to total GFCF, GDP (fisheries) to GDP (agriculture) and GFCF (fisheries) to GFCF (agriculture) (2004-05 constant prices), 1990-91 to 2014-15 Source: Authors' calculations based on GoI[b].

Table 2. GDP fisheries and capital formation at break points, and trend growth rates (Rs. billion, TE average)

\begin{tabular}{|c|c|c|c|c|c|c|}
\hline Year & $\begin{array}{c}\text { GDP } \\
\text { (Total) }\end{array}$ & $\begin{array}{c}\text { GDP } \\
\text { (Agriculture) }\end{array}$ & $\begin{array}{c}\text { GDP } \\
\text { (Fisheries) }\end{array}$ & $\begin{array}{l}\text { GFCF } \\
\text { (Total) }\end{array}$ & $\begin{array}{c}\text { GFCF } \\
\text { (Agriculture) }\end{array}$ & $\begin{array}{c}\text { GFCF } \\
\text { (Fisheries) }\end{array}$ \\
\hline $1994-95$ & 15275.1 & 4321.3 & 184.8 & 3671.4 & 399.6 & 13.4 \\
\hline $2000-01$ & 22304.2 & 5182.5 & 232.5 & 5825.0 & 577.5 & 38.5 \\
\hline 2004-05 & 27727.1 & 5491.3 & 272.1 & 7870.5 & 716.7 & 59.1 \\
\hline $2009-10$ & 41904.6 & 6572.5 & 333.8 & 15020.6 & 1173.1 & 86.3 \\
\hline $2014-15$ & 58987.0 & 7709.2 & 413.6 & 21654.7 & 1442.1 & 139.4 \\
\hline \multicolumn{7}{|l|}{ Trend growth (\%) } \\
\hline 1994-95/2000-01 & 6.5 & 3.2 & 3.7 & 8.2 & 7.0 & 20.0 \\
\hline $2000-01$ to $2004-05$ & 5.5 & 1.4 & 4.1 & 7.5 & 5.1 & 10.8 \\
\hline $2004-05$ to $2009-10$ & 8.7 & 3.7 & 4.4 & 14.0 & 10.6 & 8.3 \\
\hline $2009-10$ to $2014-15$ & 6.7 & 3.4 & 4.5 & 7.7 & 3.7 & 10.2 \\
\hline $1994-95$ to $2014-15$ & 7.1 & 2.9 & 3.8 & 9.9 & 8.0 & 12.3 \\
\hline
\end{tabular}

Source: Authors' calculations based on GoI[b].

severe, as it was during the period of 1994-95 to 200405. However, lower growths of GFCF in agriculture have an impact on regional growth and development. It could lead to lower productivity and farm income growth, especially in rural areas, and thereby consumption demands in the hinterlands of the country.

Table 2 shows triennium ending averages of GDP and GFCF for the overall economy, agricultural and fisheries sectors and trend growths rates during the sub- periods corresponding to structural breaks. The GFCF in the overall economy increased from Rs 3671 billion in 1994-95 to Rs 216 billion in 2014-15. In agricultural and allied sectors, the GFCF increased from 400 billion to 1442 million. GFCF in agriculture as a share of GFCF in the economy declined from $12.6 \%$ to $6.7 \%$, whereas the GFCF in fisheries as a share of GFCF in agriculture increased from $3.4 \%$ to $9.7 \%$. In fisheries, the GDP increased from 185 billion in 1994-95 to 414 billion in 2015-16. The sub-period growth rates 
indicates that the lowest rate of growth of capital formation in agricultural sector during 2009-10 to 2014-15, whereas in the fisheries sub-sector during 2004-05 to 2009-10. Quereshi et al. (2015) notes that the Gross Fixed Capital Formation (GFCF) in fisheries is about 6 per cent in 1990, peaked at around 16 per cent in 1999 and hovers around 10 per cent since then. Vasisht \& Singh (2009) observe that the share of fisheries in agriculture outlay has increased from 1.74\% during first plan to $5.62 \%$ during sixth plan and then declined to $3.7 \%$ during tenth plan. The share of GFCF in fisheries sub-sector in total GFCF is almost constant at around half a per cent between 1970-71 to 1985-86 and then started increasing at a steady pace during 1985-86 to 2002-03.

During the overall period of 1993-94 to 2014-15, the agricultural sector GDP has grown at the rate of $2.9 \%$, much below that of the overall economy at $7.1 \%$. The overall growth of fisheries sub-sector was a modest $3.8 \%$. On the other hand, growth in GFCF in fisheries was $12.3 \%$ compared to $8.0 \%$ in the agricultural sector.

An important observation is the declining share of agriculture in the overall GFCF, from $12.6 \%$ in $1994-$ 95 to $6.7 \%$ in $2014-15$ (table 3 ). This slide is not smooth, but characterised by noises. The share slipped to $8.3 \%$ in $2000-01$, and has risen to $10.6 \%$ in $2004-$ 05 , but has continuously slipped thereafter, except during 2001-02 to 2003-04.

Fisheries sub-sector has depicted a different trend compared to agricultural sector as a whole. The share of fishery sub-sector in agricultural GDP has gradually increased, from $3.9 \%$ in $1992-93$ to $5.3 \%$ in $2014-15$ (figure 3). Correspondingly, the share of fisheries in GFCF of agriculture has increased from $3.4 \%$ to $9.7 \%$. Further, GFCF in fisheries as a share of GDP of fisheries origin has improved to reach $34 \%$ in 2014-15 from $7 \%$ in 2003-04.

Overall, it could be noted that the share of fisheries sub-sector both in GFCF of agricultural sector and GDP agriculture have increased. The high increase of GFCF in fishery sub-sector could be due to heavy investment in aquaculture and marine fisheries (craft \& gear). The shrimp aquaculture and inland fisheries were highly promoted for export purpose by various agencies including Marine Products Export Development Agency.

By the year 1997-98, the share of GCF of fisheries in total agricultural sector GCF has surpassed fisheries sub-sector's contribution to GDP in agriculture sector. It could be the operation of ICOR and its underlying technical configuration that is leading the difference in the growths of the GDP fisheries and GFCR fisheries.

Another remarkable observation is that the growth in investment in fishery sub-sector is always higher than the growth in investment in agriculture and allied sectors. In the case of growth in the GDP, the fisheries sub-sector has performed better than the agricultural sector.

\subsection{Elasticities of gross domestic product with respect to capital formation}

The differential response of GDP with respect to capital formation over different periods has given rise to

Table 3. Summary statistics

\begin{tabular}{|c|c|c|c|c|c|}
\hline Particulars & $1994-95$ & $2000-01$ & 2004-05 & $2009-10$ & 2014-15 \\
\hline Share of GDP (Agri) in overall GDP (\%) & 28.3 & 23.2 & 19.8 & 15.7 & 13.1 \\
\hline Share of GFCF (Agri) in overall GFCF (\%) & 12.6 & 8.3 & 10.6 & 7.1 & 6.7 \\
\hline Share of GDP (Fish) in GDP(Agri) (\%) & 4.3 & 4.5 & 5.0 & 5.1 & 5.4 \\
\hline Share of GFCF (fish) in GFCF(Agri) (\%) & 3.4 & 6.7 & 8.2 & 7.4 & 9.7 \\
\hline GDP Fisheries (Rs. billon) & 184.8 & 232.5 & 272.1 & 333.8 & 413.6 \\
\hline GFCF in fisheries (Rs. billion) & 13.4 & 27.2 & 59.1 & 86.3 & 139.4 \\
\hline Share of GFCF in fisheries in GDP fisheries (\%) & 7.3 & 16.6 & 21.7 & 25.9 & 33.7 \\
\hline GFCF (Rs. billion) & 3671.4 & 5825.0 & 7870.4 & 15020.6 & 21654.7 \\
\hline Share of public capital formation in GFCF & 44.1 & 29.4 & 26.0 & 25.5 & 22.5 \\
\hline Share of private capital formation in GFCF & 55.9 & 70.59 & 74.0 & 74.5 & 77.5 \\
\hline Share of agriculture in GFCF (\%) & 10.9 & 9.9 & 9.1 & 7.8 & 6.7 \\
\hline
\end{tabular}

Source: Authors' calculations based on GoI[b]. 
Table 4. Trend in the elasticity of GDP with respect to GFCF

\begin{tabular}{lccc}
\hline Period & $\begin{array}{c}\text { Overall } \\
\text { GDP }\end{array}$ & $\begin{array}{c}\text { GDP } \\
\text { (Agricultural } \\
\text { sector) }\end{array}$ & $\begin{array}{c}\text { GDP } \\
\text { (Fisheries } \\
\text { sub-sector) }\end{array}$ \\
\hline 1994-95 to 2000-01 & 0.80 & 0.45 & 0.19 \\
$2000-01$ to 2004-05 & 0.73 & 0.27 & 0.38 \\
2004-05 to 2009-10 & 0.62 & 0.35 & 0.53 \\
$2009-10 /$ to 2014-15 & 0.88 & 0.91 & 0.44 \\
$1994-95$ to 2014-15 & 0.72 & 0.36 & 0.31 \\
\hline
\end{tabular}

Source: Authors' calculations.

Table 5. Trend in ICOR of agricultural sector and fisheries sub-sector

\begin{tabular}{lcc}
\hline Period & $\begin{array}{c}\text { ICOR } \\
\text { (Agricultural } \\
\text { sector) }\end{array}$ & $\begin{array}{c}\text { ICOR } \\
\text { (Fisheries } \\
\text { sub-sector) }\end{array}$ \\
\hline 1994-95 to 2000-01 & 3.5 & 3.2 \\
$2000-01$ to 2004-05 & 7.6 & 6.6 \\
$2004-05$ to 2009-10 & 5.8 & 6.8 \\
$2009-10$ to 2014-15 & 7.1 & 8.3 \\
$1994-95$ to 2014-15 & 5.2 & 5.8 \\
\hline
\end{tabular}

Source: Authors' calculations.

questions regarding nature of the elasticities. Table 4 provides trend in the elasticity of overall GDP, GDP from agricultural sector and GDP from fisheries subsector with respect to their corresponding capital formation. The elasticity of agricultural GDP is 0.36 , while that of fisheries is about 0.31 . The elasticities generally depict a rising trend. A probable reason could be that some sub-sectors of agriculture had remained under-invested, while others were over-capitalised.

\subsection{Incremental capital output ratio}

The incremental capital output ratio of agriculture and fisheries sector is provided in Table 5. For the overall period, the ICOR is estimated to be about 5.2 for agricultural sector and 5.8 for fisheries sub-sector. Planning commission (2012) has reported the ICOR to be about 4.05 for tenth five year plan and 6.58 for eleventh five year plan. For the twelfth five year plan, it was considered as 5.32. For both agricultural sector and for fisheries sub-sector, ICOR has increased, the increase being faster for the fisheries from 3.2 in 199495 to $2000-01$ to 8.3 in 2009-10 to 2014-15. This is an indication of the rising inefficiency in fish production systems (figure 4).

\subsection{Overcapitalisation of marine fisheries}

The marine sector in India has seen introduction of many technologies especially with regard to the craft and gear. One of the major strategies included usage of many new vessels with powerful engines. Since the marine fisheries represent an open access or common property, the individuals try to maximise net private benefit investing more in machinery and equipment. There has been an increase in the number of fishing vessels over the years leading to excess capacity in the

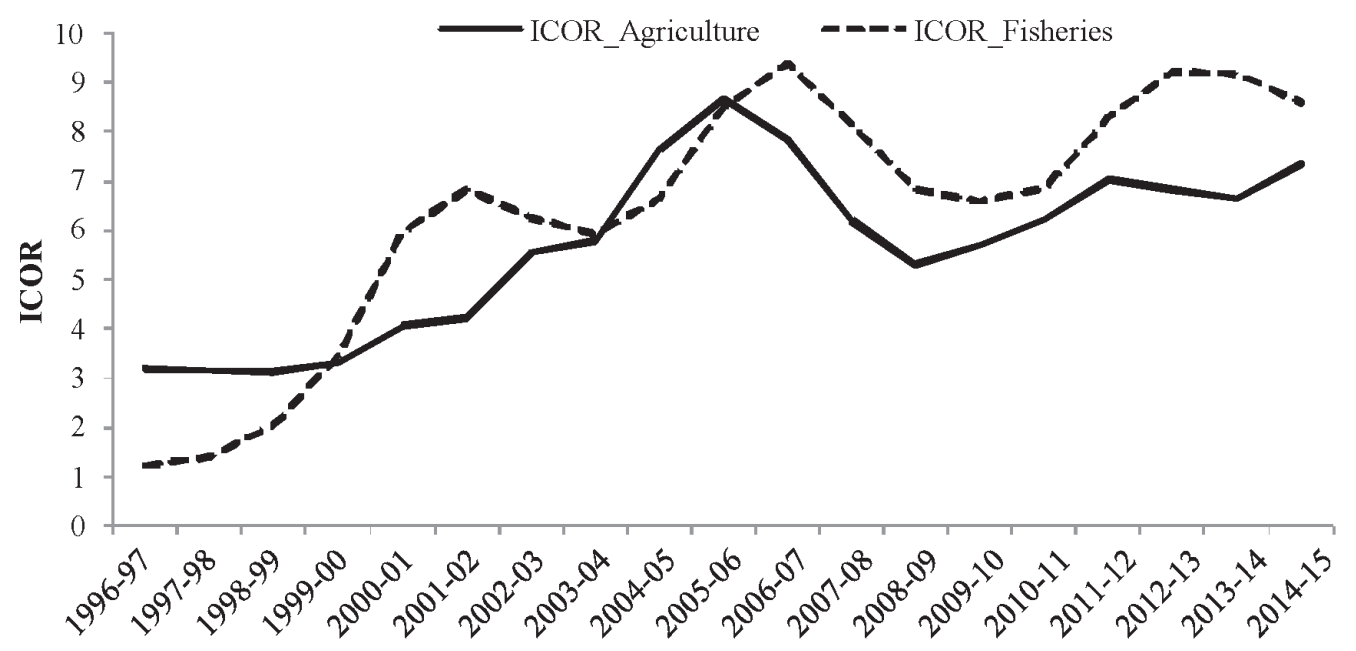

Figure 4. Movement of ICOR based on 5 year ending average, 1996-97 to 2014-15, across agriculture \& allied sectors and fisheries sub-sector

Source: Author's calculations. 
Table 6. Existing fleet in marine fisheries sector and their disproportionate capacities

\begin{tabular}{lcccc}
\hline Craft/Gear & $\begin{array}{c}\text { Recommended } \\
\text { fleet size }\end{array}$ & $\begin{array}{c}\text { Existing } \\
\text { fleet size }\end{array}$ & No. & Excess \\
\hline Mechanized multiday trawlers & 10556 & $35228^{*}$ & 1803 & 105 \\
Mechanized single day trawlers & 6638 & & & 153 \\
Mechanized gillnetters & 8019 & 20257 & 12238 & 158 \\
Mechanized hooks and lines & 449 & 1158 & 709 & 144 \\
Other mechanized crafts & 6519 & 15916 & 9397 & 125 \\
Total mechanized & 32231 & 72559 & 40328 & 18 \\
Motorized & 60218 & 71313 & 11095 & \\
\hline
\end{tabular}

Source: Government of India $(2011,2012)$.

sector. Table 6 present a picture of the existing fishing fleet (2010) as against the optimum fishing fleet estimated by the Working Group for Revalidating the Potential of Fishery Resources in the Indian EEZ appointed by the Government of India (2011). There is an obvious excess capacity in most of the fishing fleets, especially in the case of mechanized crafts. Overfishing by the outstretched fishing fleet resulting in decline in fish catch together with juvenile fishing, and other unsustainable fishing practices has affected sustainability of the marine fish system, thereby having an indirect impact on the livelihood of the fishing population.

In inland fisheries, the most important area of development is aquaculture. Brackish water aquaculture is the backbone of India's fish and fishery products exports. This sector is highly capital intensive, in terms of cost of land development and cold storage infrastructure. Further, aquaculture is very sensitive to diseases. Symptoms of unsustainability are also creeping into the inland sector, especially with respect to conversion of fertile low lying areas, mainly used for paddy cultivation for fisheries, which is said to affect the quality of land (Umamaheswari et al. 2009).

\subsection{Capital formation across institutions}

The major sources of investment are: households, public sector and corporate sector. Foreign direct investment is allowed in many areas of agriculture, especially food processing, high-tech agriculture, livestock and fisheries. In India, bulk of the capital formation in agricultural and allied sectors comes from households.

Between 2011-12 and 2016-17, the share of allied subsectors including livestock, forestry and fisheries in the overall capital formation has increased, whereas that of crops has declined, from $87.2 \%$ to $84.3 \%$ (table 7). Household's investment in fisheries has improved from $4.9 \%$ to $7.9 \%$, whereas that in crop has reduced from $86.3 \%$ to $82.8 \%$. Household investment in livestock has registered marginal improvement. However, the share of fisheries in public investment is

Table 7. Share of various sub-sectors in GFCF in agriculture by sources of investment, 2011-12 and 2015-16 (\%)

\begin{tabular}{|c|c|c|c|c|c|c|c|c|}
\hline \multirow[t]{2}{*}{ Sector } & \multicolumn{2}{|c|}{ Total } & \multicolumn{2}{|c|}{ Households } & \multicolumn{2}{|c|}{ Public } & \multicolumn{2}{|c|}{ Corporations } \\
\hline & $2011-12$ & $2015-16$ & $2011-12$ & $2015-16$ & 2011-12 & $2015-16$ & $2011-12$ & $2015-16$ \\
\hline $\begin{array}{l}\text { Agriculture, forestry } \\
\text { and fishing }\end{array}$ & 100 & 100 & 100 & 100 & 100 & 100 & 100 & 100 \\
\hline Crops & 87.2 & 84.3 & 86.3 & 82.8 & 94.8 & 94.2 & 61.8 & 61.2 \\
\hline Livestock & 7.7 & 7.9 & 8.7 & 9.3 & 0.0 & 0.0 & 22.2 & 20.8 \\
\hline Forestry \& logging & 0.7 & 1.1 & 0.0 & 0.04 & 5.2 & 5.8 & 1.0 & 0.8 \\
\hline Fishing & 4.4 & 6.7 & 4.9 & 7.9 & 0.02 & 0.0 & 14.9 & 17.2 \\
\hline
\end{tabular}

Source: Authors' calculations. 
meagre. Corporate investment in fisheries is much higher (14.9-17.2\%). The corporate investment largely concentrates on exports and domestic marketing, and does not cater to the requirement of masses involved in production.

\section{Conclusions}

The study has analysed capital formation in fisheries sub-sector. The rate of investment in fisheries has grown faster than that in the agricultural sector, but has not translated into equivalent rise in GDP from fisheries indicating declining efficiency of investment. The ICOR of fisheries increased faster than that of overall agricultural sector. Over a period of time, the marine fisheries has witnessed high rate of capitalisation, while catch per effort has been declining.

Inland fishery also faces sustainability issues in terms of environmental degradation. The shrimp aquaculture in many low lying areas is at the cost of paddy cultivation. Aquaculture is susceptible to a host of diseases. Being mostly export-oriented, the value chain requires adherence to quality standards.

In order to attain food and nutritional security, fish production needs to be boosted, which requires heavy investment, especially in feed production, spawn centres, disease surveillance, creation of infrastructure like cold storage, quality fish landing centres, energy efficient vessels, equipping with marine safety measures, development of market yards, waste disposal/ processing plants, and strict adherence with SPS measures.

However, recent trends, as indicated in the analysis show that the capital formation in fishery sector is almost exclusively by private sector. Public sector is conspicuous by its near absence. This needs to be rectified by prioritizing the avenues of investment. Also, the efficiency of capital needs to be improved, which requires improving the technical conditions of production. Technology development in fishery sector including for aquaculture, and its dissemination to the clients through efficient extension system is critical towards this. Of overwhelming importance are the human development needs of the fishers and their households through education, skill up-gradation and enhancing access to basic human needs. Development of fishery sector would help to achieve this, and thereby towards attaining sustainable development goals.

\section{References}

Bai, J. (1997). Estimating multiple breaks one at a time. Econometric Theory, 13, 315-352.

Bai, J., \& Perron, P. (2003). Computation and analysis of multiple structural change models. Journal of Applied Econometrics, 18, 1-22.

Balakrishnan, P., \& Parameshwaran, M. (2007). Understanding economic growth in India: a prerequisite. Economic and Political Weekly, 42 (7), 29152922.

Barik, N.K. (2017). Freshwater fish for nutrition security in India: vvidence from FAO data. Aquaculture Reports, 7, 1-6.

Bathla, S. (2014). Public and private capital formation and agricultural growth in India: state level analysis of interlinkages during pre- and post-reform periods. Agricultural Economics Research Review, 27 (1), 1936.

Bhalla, S. (1987), Trend in employment in Indian agriculture laborers: a state-wise analysis. Indian Journal of Agricultural Economics, 42(4), 537-560.

Birthal, P. S. , \& Taneja, V. K . (2006). Livestock sector in India: opportunities and challenges for small holders. In: Proceedings of an ICAR-ILRI International Workshop, NCAP, New Delhi and ILRI, Nairobi.

Chand, R. (2000). Emerging trends and regional variations in agricultural investments and their implications for growth and equity. Policy Paper No. 11, National Institute of Agricultural Economics and Policy Research, New Delhi.

Chand, R., \& Parappurathu, S. (2012). Temporal and spatial variations in agricultural growth and its determinants. Economic and Political Weekly, 47 (26\&27), 55-64.

Delgado, C., Rosegrant, M., Steinfeld, H., Ehui. S., \& Courbois C. (1999). Livestock 2020: the new food revolution: Discussion Paper EPTD 28, International Food Policy Research Institute, Washington DC.

Dhawan, B.D. (1996). Relationship between public and private investments in Indian agriculture with special reference to public canals. Indian Journal of Agricultural Economics, 5 (1\&2), January-June.

Fan, S., \& Hazell, P. (2001). Should developing countries invest more in less-favoured areas? an empirical analysis of rural India. Economic and Political Weekly, 35( 17), 1455-1464.

FAO. (2016). The state of world fisheries and aquaculture 2016: Contributing to food security and nutrition for all. Rome. 
GoI (Government of India). (2011). Report of working group on revalidation of fisheries potential of fishery resources in the Indian Exclusive Economic Zone. Department of Animal Husbandry Dairying and Fisheries, Ministry of Agriculture, New Delhi.

.(2012). Marine fisheries census 2010, Part 1. Ministry of Agriculture, New Delhi and CMFRI, Kochi.

.(2014). Handbook on fisheries statistics. Department of Animal Husbandry, Dairying and Fisheries, Ministry of Agriculture, New Delhi.

.Various Years[a]. State-wise and item-wise estimates of value of output from agriculture and allied sectors. Central Statistical Organization, Ministry of Statistics and Programme Implementation, New Delhi.

.Various Years [b]. National accounts statistics. Central Statistical Organization, Ministry of Statistics and Programme Implementation, New Delhi.

Gulati, A., \& Bathla, S. (2001). Capital formation in Indian agriculture: re-visiting the debate. Economic and Political Weekly, May 19, 1697-1708.

Indian Council of Agricultural Research. (ICAR). (2012). Vision 2030. Ministry of Agriculture, New Delhi.

Joshi, P.K., Gulati, A., Birthal, P.S., \& Tewari, L. (2004). Agriculture diversification in South Asia: patterns, determinants and policy implications, Economic and Political Weekly. 39 (24), 2457-2467.

Mishra, S.N., \& Chand, R. (1995). Public and private capital formation in Indian agriculture: comments on the complementarity hypothesis and others. Economic and Political Weekly, 30(25), A64-A79.

Mitra, A. (1996). Public and private investments in agriculture. In: Agricultural development paradigm for the Ninth Plan under new economic environment (B.M.Desai, ed.). Oxford \& IBH, New Delhi.
Planning Commission. (2012). Report of the working-group on estimation of investment, its composition and trend for twelfth five-year plan (2012-13 to 2016-17). Perspective Planning Division, Government of India, New Delhi.

Qureshi, N.W., Achoth, L., Krishnan, M., Prakash, Ananthan P.S., Kumar, N.R., \& Pandey, S.K. (2015). Misplaced priorities and lopsided investments: a macroscan of agriculture, livestock and fisheries sectors in India. Agricultural Economics Research Review, 28 (Conference Number), 25-34.

Rao, C.H. H. (1989). Technological change in Indian agriculture: emerging trends and perspectives, Indian Journal of Agricultural Economics, 44 (4), 385-398.

Shetty, S.L. (1990). Investment in agriculture: brief review of recent trends. Economic and Political Weekly, 25(7\&8), 389-398.

Singh, A. (2011). The changing landscape of public expenditure and investments in agriculture: implications for growth trajectory. Indian Journal of Agricultural Economics, 66(3), 301-313.

Umamaheswari, L., Hattab, K.O., Nasurudeen, P, \& Selvaraj, P. (2009). Should shrimp farmers pay paddy farmers? :the challenges of examining salinization externalities in South India. Working Paper No. 41-09, South Asian Network for Development and Environmental Economics (SANDEE), Kathmandu, Nepal.

UNDP (United Nations Development Programme). (2018). Sustainable development goals. http://www.undp.org/ content/undp/en/home/sustainable-developmentgoals.html

Vasisht, A.K., \& Singh, D.R. (2009). An analysis of capital formation in fisheries sector in India. Asian Fisheries Science, 22, 823-837. 